\title{
KONSENTRASI MERKURI PADA RAMBUT KEPALA DAN KESEHATAN MASYARAKAT PADA LOKASI PENAMBANGAN EMAS TRADISIONAL BULADU KABUPATEN GORONTALO UTARA
}

\section{Mercury Concentration on Hair and Health of Community Location in the Traditional Gold Mining Buladu District Gorontalo North}

\author{
Marike Mahmud $^{\mathrm{a}}$, Fitryane Lihawa ${ }^{\mathrm{b}}$, Beby Banteng ${ }^{\mathrm{c}}$, Frice Desei ${ }^{\mathrm{c}}$, Yanti Saleh ${ }^{\mathrm{d}}$ \\ ${ }^{a}$ FakultasTeknik, Universitas Negeri Gorontalo, Jalan Jenderal Sudirman No 6, Kota Gorontalo, Indonesia \\ -marikemahmud@yahoo.com \\ ${ }^{b}$ PSLK, Universitas Negeri Gorontalo, Jalan Jenderal Sudirman No 6, Kota Gorontalo, Indonesia \\ ${ }^{c}$ Fakultas Teknik, Universitas Negeri Gorontalo, Jalan Jenderal Sudirman No 6, Kota Gorontalo, Indonesia \\ ${ }^{d}$ PSLK, Universitas Negeri Gorontalo, Jalan Jenderal Sudirman No 6, Kota Gorontalo, Indonesia
}

\begin{abstract}
This study aims to identify mercury concentrations in head hair and its effect on public health at the traditional gold mining. The study was conducted at the gold mining, Buladu Village, North Gorontalo Regency. Samples were taken randomly from human head hair. Samples of public health condition were taken from respondents who served as the samples of mercury concentrations in the head hair. The number of respondents was 20 people. The samples of mercury in the head hair were analyzed at the Integrated Research and Testing Laboratory of UGM by using mercury analyzer. The quality standard used as a reference to the mercury concentrations in the head hair was the recommendation of the National Research Council (NCR), i.e. 12 ppm. The results of the analysis of the public health were tabulated and then interpreted. The results of the analysis indicated that the highest mercury concentration in the head hair was $952.85 \mathrm{mg} / \mathrm{kg}$ and the lowest was $0.03 \mathrm{mg} / \mathrm{kg}$ with an average mercury concentration of $55.09 \mathrm{mg} / \mathrm{kg}$. This result was above the threshold quality standards established by NCR, i.e. 12 ppm. Many factors affect the mercury concentrations in humans, including education, income, environmental sanitation and food consumption. Waste dumped directly into the river will affect river water and marine aquatic animals. The consumption of food taken from the waters of Sulawesi Sea affects influence the mercury concentrations in the head hair.
\end{abstract}

Keywords: Mercury in head hair, public health.

(Diterima: 20-03-2017; Disetujui: 07-11-2017)

\section{Pendahuluan}

Merkuri merupakan unsur yang sangat beracun. Pada keracunan tingkat ringan timbul pusing, sakit kepala dan mudah lelah. Pada keracunan tingkat berat menyebabkan kerusakan ginjal, sendi-sendi kaku, penglihatan terganggu, kelainan sistem syaraf dan dapat menimbulkan kematian seperti yang terjadi pada kasus di Minamata.

Hasil penelitian yang dilakukan oleh Mahmud et al. (2014) menunjukkan bahwa jumlah tromol yang berada di Desa Sumalata sebesar 152 tromol, Desa Padengo sebesar 52 tromol, Desa Ilangata Barat sebesar 133 tromol dan Desa Ilangata sebesar 128 tromol. Total sebanyak 204 tromol sisa limbah yang dibuang dan dialirkan ke sungai yang aliran limbahnya mengalir dan masuk ke Laut Sulawesi. Sebanyak 261 tromol mencemari air tanah di daerah sekitar Ilangata. Total jumlah tromol di ke dua lokasi di Gorontalo Utara berjumlah 465 tromol. Berdasarkan hasil penelitian ini maka dikhawatirkan akan membahayakan masyarakat yang hidup di Kabupaten Gorontalo Utara. Jumlah ini lebih tinggi jika dibandingkan dengan jumlah tromol yang terdapat di Kecamatan Tulabolo yang berjumlah 188 tromol (Mahmud, 2012).

Hasil penelitian awal yang dilakukan oleh Mahmud et al. (2014) menunjukkan bahwa kualitas air pada muara Laut Sulawesi juga sebesar 0.008 mg/l. KepMen LH No. Kep 51 Tahun 2004 tentang baku mutu kualitas air laut bagi kehidupan biota laut untuk parameter air raksa sebesar $0.001 \mathrm{mg} / \mathrm{l}$. Konsentrasi merkuri sebesar $0.008 \mathrm{mg} / \mathrm{l}$ sudah berada di atas ambang yang disyaratkan. Hal ini akan membahayakan utamanya manusia yang mengkonsumsi hewan aquatik yang hidup di perairan Laut Sulawesi. Tingginya konsentrasi merkuri pada air laut akan mencemari ikan di sekitarnya. Hal ini akan masuk pada tubuh manusia dan terakumulasi. Penelitian ini penting dilakukan untuk mengetahui berapa besar konsentrasi merkuri masuk pada tubuh manusia.

Penelitian yang dilakukan oleh Panda et al. (2003) di Sungai Kahayan menunjukkan bahwa merkuri di sepanjang Sungai Kahayan mengancam penduduk yang mengkonsumsi ikan di sungai tersebut. Akumulasi merkuri tertinggi dalam sedimen sungai (0.336 ug) dikutip dalam daging M.numerus (0.303 $\mathrm{ug} / \mathrm{g} \pm 0.342)$ dan air $(0.058 \mathrm{mg} / \mathrm{l})$. Asupan merkuri mingguan yang dapat ditoleransi menurut WHO adalah 24.4 ug sehari jika dimungkinkan seseorang mengkonsumsi $100 \mathrm{~g}$ daging M.Numerus sehari, 30.3 ug/g yang masuk ke tubuh. Penelitian yang dilakukan oleh Brabo et al. (2003) konsentrasi merkuri di sedimen dasar tanpa dipengaruhi kegiatan antropogenik di Acre State sebesar $0.042 \mathrm{mg} / \mathrm{kg}$. 
Salah satu cara untuk mendeteksi tingkat konsentrasi merkuri pada manusia adalah melalui rambut. Kosentrasi merkuri pada rambut cukup persisten sehingga tidak hilang karena pencucian dengan shampoo maupun pengecatan rambut, namun dapat menurun sebanyak $30-50 \%$ bila rambut diluruskan atau dikeriting karena pelurus rambut mengandung unsur thyoglycolic acid yang mempunyai efek mengurangi $\mathrm{MeHg}$ pada rambut (Chamid et al., 2010).

Umumnya konsentrasi merkuri pada rambut memberikan informasi terhadap pemaparan $\mathrm{MeHg}$ (Sari et al., 2012). Dengan demikian kegiatan tambang tradisional yang berada di Kecamatan Sumalata memerlukan penelitian yang mendalam yaitu masalah kegiatan tambang tradisional akan memberi dampak pencemaran terhadap ekosistem di Sungai Pasolo dan mengancam penduduk yang mengkonsumsi ikan atau air dari sungai tersebut. Hasil akhir dari pencemaran yaitu masyarakat yang mengkonsumsi ikan di Laut Sulawesi, akan masuk ke tubuh manusia. Salah satu cara untuk mengetahui sudah seberapa jauh paparan merkuri pada tubuh manusia adalah pengukuran merkuri pada rambut kepala. Penelitian ini bertujuan untuk mengetahui konsentrasi merkuri pada rambut kepala dan pengaruhnya pada kesehatan masyarakat di penambangan emas tradisional Buladu.

\section{Metode Penelitian}

Penelitian dilakukan di Penambangan Emas Buladu. Pengambilan sampel pada rambut kepala sebanyak 20 responden. Pengambilan data kesehatan masyarakat dilakukan pada responden yang diukur konsentrasi merkuri pada rambut kepala. Pengambilan sampel dilakukan secara acak. Analisis sampel merkuri di dalam air dan sedimen dengan menggunakan mercury analyzer di Laboratorium Penelitian dan Pengujian Terpadu UGM. Baku mutu yang dijadikan acuan untuk kontaminasi merkuri di rambut kepala yakni direkomendasikan oleh NCR sebesar 12 ppm. Analisis data secara deskriftif dengan menggunakan tabel, selanjutnya diinteprestasi.

\section{Hasil dan Pembahasan}

\subsection{Konsentrasi Merkuri di Rambut Kepala Masyarakat di Penambangan Emas Buladu}

Kadar merkuri dalam rambut kepala dapat dipakai sebagai indikator absorbsi akibat pemaparan yang telah berlangsung satu sampai beberapa bulan terakhir. Konsentrasi merkuri di rambut kepala bagi masyarakat yang hidup di lokasi penambangan emas Buladu menunjukkan bahwa konsentrasi merkuri tertinggi sebesar $952.85 \mathrm{mg} / \mathrm{kg}$ dan terendah sebesar $0.03 \mathrm{mg} / \mathrm{kg}$ dengan rata-rata konsentrasi merkuri sebesar 55.09 $\mathrm{mg} / \mathrm{kg}$. Hasil ini sudah sangat tinggi jika dibandingkan dengan penelitian di penambangan lain di Provinsi Gorontalo yang dilakukan oleh Mahmud (2012), dimana konsentrasi merkuri rata-rata sebesar 4.04 $\mathrm{mg} / \mathrm{kg}$. Penelitian yang telah dilakukan oleh Rumatoras et al. (2016) menunjukkan bahwa konsentrasi merkuri pada rambut penduduk di Desa Kayeli berkisar antara $0.10-3.25 \mathrm{ppm}$ dan sampel pembanding $0.42 \mathrm{ppm}$. Hasil ini lebih rendah jika dibandingkan dengan konsentrasi merkuri di Penambangan emas Buladu yang rata-rata $55.09 \mathrm{mg} / \mathrm{kg}$. Penelitian yang dilakukan oleh Sumantri, dkk (2014) pada pekerja tambang di Desa Cisarua menunjukkan bakwa dengan CI 95\% rata-rata akumulasi logam merkuri dalam sampel rambut pekerja PETI di Desa Cisarua Tahun 2013 adalah 2.03 ppm sampai dengan 9.04 ppm atau terdapat 24 orang atau $60 \%$ orang mengalami keracunan lebih dari 2 ppm. Disimpulkan bahwa faktor masa kerja memiliki korelasi yang kuat dengan akumulasi di rambut kepala pada pekerja PETI. Hasil ini lebih rendah jika dibandingkan dengan kontaminasi merkuri pada rambut kepala manusia di Penambangan Emas Buladu. Hal ini membuktikan bahwa Penambangan Emas Buladu sangat membutuhkan perhatian yang serius.

Hasil penelitian menunjukkan bahwa konsentrasi merkuri di rambut kepala bagi masyarakat di Penambangan Emas Buladu, dari 20 sampel, 20\% melebihi batas ambang yang ditetapkan, 20\% cenderung mendekati batas ambang dan $60 \%$ berada di bawah ambang batas yang direkomendasikan oleh NCR sebesar 12 ppm. Berdasarkan hasil ini maka masyarakat yang bermukim di lokasi penambangan emas Buladu telah terkontaminasi merkuri. Hasil analisis konsentrasi merkuri pada manusia ditunjukkan pada Tabel 1.

Tabel 1. Hasil Konsentrasi Merkuri Pada Manusia

\begin{tabular}{lccc}
\hline No & Umur (Tahun) & $\begin{array}{c}\text { Hasil } \\
\mathrm{mg} / \mathrm{kg}\end{array}$ & $\begin{array}{c}\text { Analisis } \\
\text { Mutu } \\
\text { mg }\end{array}$ \\
\hline R1 & 21 & 7.17 & 12 \\
R2 & 28 & 3.00 & 12 \\
R3 & 14 & 1.98 & 12 \\
R4 & 15 & 15.80 & 12 \\
R5 & 47 & 7.21 & 12 \\
R6 & 31 & 4.76 & 12 \\
R7 & 22 & 2.50 & 12 \\
R8 & 41 & 3.39 & 12 \\
R9 & 23 & 27.79 & 12 \\
R10 & 21 & 3.32 & 12 \\
R11 & 43 & 7.42 & 12 \\
R12 & 52 & 0.03 & 12 \\
R13 & 20 & 5.07 & 12 \\
R14 & 45 & 12.22 & 12 \\
R15 & 36 & 5.42 & 12 \\
R16 & 47 & 3.27 & 12 \\
R17 & 30 & 7.17 & 12 \\
R18 & 34 & 5.21 & 12 \\
R19 & 16 & 3.87 & 12 \\
R20 & 41 & 952.85 & 12 \\
\hline
\end{tabular}

Sumber : Mahmud et al. (2016)

Hasil analisis menunjukkan bahwa umur tidak memberi pengaruh yang signifikan terhadap konsentrasi merkuri di rambut kepala pada masyarakat yang hidup di lokasi Penambangan Tradsional Emas Buladu. Hasil analisis menunjukkan bahwa responden umur 52 tahun teridentifikasi memiliki $0.03 \mathrm{mg} / \mathrm{kg}$ dan 
umur 15 tahun memiliki konsentrasi merkuri di rambut kepala sebesar $15.80 \mathrm{mg} / \mathrm{kg}$. Responden R9 mengandung kadar merkuri pada rambut kepala sebesar $27.79 \mathrm{mg} / \mathrm{kg}$ dan responden R.20 dengan umur 41 tahun memiliki kadar merkuri $952.85 \mathrm{mg} / \mathrm{kg}$. Banyak faktor yang memberi pengaruh terhadap kadar merkuri di rambut kepala. Berdasarkan hasil ini maka masyarakat di lokasi penambangan emas Tulabolo sudah terkontaminasi merkuri. Penelitian yang dilakukan oleh Junita (2013) menujukkan bahwa tidak terdapat perbedaan yang bermakna antara umur dan keracunan merkuri. Risiko keracunan merkuri lebih besar terjadi pada pekerja PETI yang memiliki masa kerja lebih lama dibandingkan yang tidak lama.

\subsection{Pengaruh Konsentrasi Merkuri di Rambut Kepala Dengan Kesehatan Masyarakat}

Berdasarkan hasil penelitian maka masyarakat di penambangan emas Buladu sudah terkontaminasi merkuri. Hal ini berpotensi terhadap gangguan masyarakat di sekitar. Hasil wawancara kondisi social masyarakat di penambangan emas Buladu ditunjukkan pada Tabel 2.

\begin{tabular}{clcc}
\multicolumn{4}{c}{ Tabel 2. Hasil wawancara kondisi sosial masyarakat } \\
\hline No. & \multicolumn{1}{c}{ Indikator } & Jumlah & $\%$ \\
\hline 1 & Tingkat Pendidikan & \\
& SD tamat & 15 & 75 \\
& SMP tamat & 1 & 5 \\
& SMA tamat & 4 & 20 \\
\hline 2 & Pekerjaan & \\
& Menambang & 14 & 70 \\
& Berkebun & \\
& Berdagang & 3 & 15 \\
& IRT & 3 & 15 \\
\hline \multirow{2}{*}{3} & Pendapatan & & \\
& < Rp. 100.000 & 1 & 5 \\
& Rp.100.000-500.000 & 4 & 20 \\
& Rp.500.000- & 8 & 40 \\
& Rp.1.000.000 & & \\
& $>$ Rp.1.000.000 & 7 & 35 \\
\hline \multicolumn{2}{l}{ Sumber: } & Mahmud et al. (2016).
\end{tabular}

Hasil wawancara menunjukkan bahwa tingkat pendidikan masyarakat di lokasi penambangan SD tamat sebesar 75\%, SMP Tamat 5\% dan SMA tamat sebanyak $20 \%$. Berdasarkan hasil ini maka sebagian besar masyarakat yang hidup di lokasi penambangan hanya memiliki tingkat pendidikan rendah. Tingkat pendidikan rendah menyebabkan mereka sulit mendapatkan pekerjaan lain selain menambang. Hasil wawancara menunjukkan bahwa $70 \%$ masyarakat bekerja sebagai penambang. Tingkat pendidikan yang rendah juga memicu masyarakat bergantung hidupnya pada penambangan tradisional. Tingkat pendidikan yang rendah menyebabkan mereka tidak menyadari akan bahaya keracunan merkuri bagi masyarakat.

Hasil wawancara menunjukkan bahwa penduduk yang bermukim di lokasi penambangan emas Buladu memiliki pendapatan rendah yakni $5 \%$ berkisar < Rp.100,000, 20\% berkisar Rp. 100,000 - Rp. 500,000, $40 \%$ berkisar Rp. 500,000 - Rp. 1,000,000 dan 35\% di atas Rp. 1,000,000. Para penduduk yang tinggal di lokasi penambangan ini lebih besar hidupnya bergantung pada kegiatan tambang tradisional. Hanya $15 \%$ yang hidupnya dari berdagang.

Hasil wawancara kondisi kesehatan masyarakat di lokasi penambangan emas ditunjukkan pada Tabel 3.

\begin{tabular}{|c|c|c|c|}
\hline No & Kondisi Masyarakat & Jumlah & $\%$ \\
\hline \multirow[t]{14}{*}{1} & $\begin{array}{l}\text { Jenis penyakit yang } \\
\text { diderita }\end{array}$ & & \\
\hline & - Gangguan hati & 2 & 10 \\
\hline & - Sakit kepala & 13 & 65 \\
\hline & - Berak darah & - & \\
\hline & - Gangguan penglihatan & - & \\
\hline & - Pusing-pusing & 4 & 20 \\
\hline & - Mual & - & - \\
\hline & - Tremor & 3 & 15 \\
\hline & - Asma & 3 & 15 \\
\hline & - Cepat lelah & 10 & 50 \\
\hline & - Gangguan ginjal & 1 & 5 \\
\hline & - Sakit perut & 8 & 40 \\
\hline & - Nyeri tumit/ kram & - & \\
\hline & $\begin{array}{l}\text { - Sakit pinggang dan } \\
\text { rasa kaku sendi }\end{array}$ & 1 & 5 \\
\hline \multirow{6}{*}{2} & $\begin{array}{ll}\text { Sarana } & \text { Penyembuhan }\end{array}$ & & \\
\hline & Penyakit & & \\
\hline & -Dr Praktek & 2 & 10 \\
\hline & -Puskesmas/RSU & 13 & 65 \\
\hline & -Tidak berobat & 1 & 5 \\
\hline & -Beli obat di toko & 4 & 20 \\
\hline \multirow[t]{6}{*}{3} & Lama penyakit & & \\
\hline & $1-2$ tahun terakhir & 10 & 50 \\
\hline & $3-4$ tahun terakhir & 3 & 15 \\
\hline & $5-6$ tahun terakhir & 6 & 30 \\
\hline & $>6 \mathrm{Thn}$ & - & \\
\hline & Kurang dari 1 tahun & 1 & 5 \\
\hline \multirow[t]{3}{*}{4} & Tempat pembuangan tinja & & \\
\hline & $\mathrm{Wc}$ & 1 & 5 \\
\hline & Sungai & 19 & 95 \\
\hline \multirow[t]{3}{*}{5} & $\begin{array}{l}\text { Tempat pembuangan } \\
\text { sampah }\end{array}$ & & \\
\hline & - Di Tanah & 14 & 70 \\
\hline & - $\quad$ Sungai & 6 & 30 \\
\hline
\end{tabular}

Hasil wawancara menunjukkan bahwa beberapa jenis penyakit yang diderita oleh masyarakat yang hidup di lokasi penambangan yakni gangguan hati, $2 \%$, sakit kepala $65 \%$, pusing-pusing $20 \%$, tremor $15 \%$, asma $15 \%$, cepat lelah 50\%, gangguan ginjal 5\%, sakit perut $40 \%$ dan nyeri tumit dan sakit pinggang $5 \%$. Hasil wawancara menujukkan sudah ada gejala-gejala akibat keracunan merkuri. Berdasarkan hasil ini maka perlu segera dibuatkan model pengelolaan penambangan emas yang ramah lingkungan sehingga tidak akan membahayakan masyarakat.

Hasil wawancara menunjukkan bahwa masyarakat menggunakan sarana penyembuhan penyakit $65 \%$ menggunakan puskesmas, $20 \%$ beli obat di toko, $10 \%$ ke dokter praktek dan 5\% memilih tidak berobat. Lama penyakit diderita 1-2 tahun 50\%, 3-5 tahun 15\% dan 56 tahun $30 \%$. Berdasarkan hasil ini maka masyarakat sudah menyadari pentingnya mengobati penyakit ketika menderita sakit. Kondisi penggunaan air masyarakat ditunjukkan pada Tabel 4.

Hasil wawancara menunjukkan bahwa $100 \%$ masyarakat mengunakan air sungai untuk mandi dan mencuci. Hal ini membahayakan karena air sungai digunakan sebagai tempat buangan limbah pengolahan 
emas. Hal ini harus segera diperhatikan karena proses masuknya merkuri dapat melalui kulit.

Tabel 4. Kondisi Penggunaan Air Masyarakat

\begin{tabular}{|c|c|c|c|}
\hline No & Kondisi Masyarakat & Jumlah & $\%$ \\
\hline \multirow[t]{3}{*}{1} & Jarak sumur dengan sungai & & \\
\hline & -Air sumur jauh dari sungai & 8 & 40 \\
\hline & -PDAM & 12 & 60 \\
\hline \multirow[t]{2}{*}{2} & Konsumsi Air Minum & & \\
\hline & $\begin{array}{l}-2.25 \text { liter } \\
->2.5 \text { liter }\end{array}$ & 20 & 100 \\
\hline \multirow[t]{4}{*}{3} & Penggunaan air sungai & & \\
\hline & -Mandi & 20 & 100 \\
\hline & -Mencuci & 20 & 100 \\
\hline & -BAB & & \\
\hline \multirow[t]{2}{*}{4} & $\begin{array}{l}\text { Penggunaan air sungai untuk } \\
\text { mandi }\end{array}$ & 20 & 100 \\
\hline & -2 x sehari & 20 & 100 \\
\hline
\end{tabular}

Hasil wawancara menunjukkan bahwa sanitasi lingkungan masyarakat yang hidup di penambangan memiliki sanitasi yang buruk. Hal itu ditandai Sungai Pasolo 95\% sebagai dengan tempat buang air besar dan hanya 5\% menggunakan WC. Sebanyak $70 \%$ menggunakan tanah sebagai tempat pembuangan sampah dan $30 \%$ membuang sampah di sungai. Hal ini dapat memperburuk kesehatan amsyarakat yang hidup di lokasi penambangan emas Buladu.

Rendahnya pendapatan menyebabkan menyebabkan $100 \%$ masyarakat menggunakan air sungai untuk mandi, mencuci dan buang air besar. Hal ini akan menyebabkan Sungai Pasolo tidak layak digunakan sebagai sumber air bersih masyarakat. Masyarakat menggunakan sungai sebagai tempat buang air besar dan mandi menunjukkan bahwa sanitasi lingkungan tidak berjalan dengan baik. Hal ini dipicu oleh rendahnya tingkat pendidikan. Hasil wawancara hubungan antara umur, lama tinggal dan jarak tempat tinggal dengan konsentrasi merkuri di rambut kepala ditunjukkan pada Tabel 5.

Hasil penelitian menunjukkan bahwa konsentrasi merkuri tertinggi pada rambut kepala yakni responden (R20) telah terkontaminasi merkuri. Responden ini memiliki umur 41 tahun, lama tinggal 12 tahun dan jarak lokasi tempat tinggal dengan sungai $20 \mathrm{~m}$. Hasil konsentrasi merkuri sebesar $952.85 \mathrm{mg} / \mathrm{kg}$. Hasil terendah sebesar $0.03 \mathrm{mg} / \mathrm{kg}$ pada usia 52 tahun dengan lama tinggal di atas 20 tahun. Berdasarkan hal ini maka lama tinggal, umur dan jarak lokasi tempat tinggal tidak memberi pengaruh.

Hasil penelitian ini berbeda jika dibandingkan dengan penelitian yang dilakukan oleh Asiah et al. (2015). Hasil penelitian yang dilakukan oleh Asiah et al. (2015) mengukur konsentrasi merkuri pada manusia melalui urin. Penelitiannya menunjukkan bahwa konsentrasi merkuri pada urin di Desa Panton Kecamatan Sawang Kabupaten Aceh Selatan rata-rata $2.82 \mathrm{ug} / \mathrm{l}(\mathrm{SD} \pm 0.57)$, berada di bawah standar yang ditetapkan oleh $\mathrm{WHO}<4 \mathrm{ug} / \mathrm{l})$. Walaupun demikian lama kerja (dalam tahun) berpengaruh secara signifikan $(\mathrm{P}<0.05)$ terhadap kadar merkuri pada pekerja tambang emas
Tabel 5. Indikator kesehatan masyarakat dengan jumlah konsentrasi merkuri di rambut kepala

\begin{tabular}{lcccc}
\hline $\begin{array}{l}\text { Res } \\
\text { ponden }\end{array}$ & Umur & $\begin{array}{c}\text { Lama } \\
\text { Tinggal }\end{array}$ & $\begin{array}{c}\text { Jarak } \\
\text { Tempat } \\
\text { Tinggal } \\
\text { dengan } \\
\text { tambang }\end{array}$ & $\begin{array}{c}\text { Merkuri } \\
\text { (ppm) }\end{array}$ \\
\hline R1 & 21 & 21 & 10 & 7.17 \\
R2 & 28 & 28 & 20 & 3.00 \\
R3 & 14 & 8 & 15 & 1.98 \\
R4 & 15 & 15 & 10 & 15.80 \\
R5 & 47 & 20 & 20 & 7.21 \\
R6 & 31 & 20 & 15 & 4.76 \\
R7 & 22 & 10 & 10 & 2.50 \\
R8 & 41 & 12 & 10 & 3.39 \\
R9 & 23 & 1 & 15 & 27.79 \\
R10 & 21 & 21 & 5 & 3.32 \\
R11 & 43 & $>20$ & 300 & 7.42 \\
R12 & 52 & $>20$ & 15 & 0.03 \\
R13 & 20 & 10 & 20 & 5.07 \\
R14 & 45 & 10 & 15 & 12.22 \\
R15 & 36 & 10 & 100 & 5.42 \\
R16 & 47 & 5 & 10 & 3.27 \\
R17 & 30 & 30 & 20 & 7.17 \\
R18 & 34 & 15 & 10 & 5.21 \\
R19 & 16 & 3 & 5 & 3.87 \\
R20 & 41 & 12 & 20 & 952.85 \\
\hline Sumber $: M a h m$ & & & \\
\hline
\end{tabular}

Hasil penelitian yang dilakukan oleh Junita (2013) menunjukkan bahwa rata-rata pekerja berumur 34.05 tahun, masa kerja 8.7 tahun, jam kerja 8.30 jam. Konsumsi rata-rata ikan pekerja adalah 466 gram. Gangguan kesehatan pada pekerja diantaranya tremor, sering kesemutan, otot wajah kaku, letih, pegal, nyeri, gatal-gatal, sakit pada pinggang, sakit kepala, pusing dll. Tidak terdapat perbedaan bermakna antara umur dan keracunan merkuri. Tidak terdapat perbedaan bermakna antara status gizi dengan keracunan merkuri. Risiko lebih besar terjadi pada pekerja tambang yang memiliki masa kerja lebih lama. Gejala-gejala yang sama sudah terjadi pada masyarakat yang hidup dipenambangan emas Buladu. Hasil penelitian yang dilakukan oleh Xing et al. ( 2013) menunjukkan bahwa konsentrasi merkuri pada rambut kepala pada daerah Beijing residents yang tidak terpapar berkisar antara $1.3-2.5 \mathrm{ug} / \mathrm{g}$ dengan kadar kalsium berkisar antara 543.8 - $1172.1 \mathrm{ug} / \mathrm{g}$. Lokasi yang terpapar seperti Wanshan residents, konsentrasi merkuri berkisar antara 3.7 - $27.3 \mathrm{ug} / \mathrm{g}$ dengan kadar kalsium berkisar antara 658.5 - $1379.3 \mathrm{ug} / \mathrm{g}$. Sampel yang dilakukan pada penambang di Wanshan menunjukkan konsentrasi merkuri berkisar antara 127.4 - $550.3 \mathrm{ug} / \mathrm{g}$ dengan kadar kalsium 987-1696.2 ug/g. Berdasarkan hasil ini wilayah terpapar lebih tinggi khususnya pada penambang emas.

Toksisitas merkuri pada manusia dibedakan menurut bentuk senyawa $\mathrm{Hg}$ yang inorganic dan organic. Keracunan inorganic $\mathrm{Hg}$ seperti gejala tremor pada orang dewasa. Gejala ini dikenal pada abad ke 18 yang disebut " topi bergoyang". Gejala berlanjut dengan tremor pada otot muka, yang kemudian merambat pada jari-jari tangan. Bila keracunan berlanjut tremor pada lidah, berbicara terbata-bata, berjalan terlihat kaku dan hilang keseimbangan. Perubahan hilangnya daya ingat dapat juga terjadi pada toksisitas $\mathrm{Hg}$ tersebut. 
Banyak faktor yang memberi pengaruh kepada manusia diantaranya tingkat pendidikan, pendapatan, sanitasi lingkungan dan kosumsi makanan. Pola pembuangan limbah yang dibuang langsung ke sungai akan memberi dampak terhadap air sungai. Laut sebagai penerima limbah akan memdapatkan dampak akan hal ini. Hasil penelitian bahwa konsentrasi merkuri pada air laut cenderung mendekati ambang batas baku mutu air laut dan konsentrasi merkuri pada sedimen telah berada di atas baku mutu, maka paparan pada manusia dapat terjadi karena konsumsi makanan khususnya ikan di perairan Sumalata.

Hasil analisis menunjukkan bahwa rata-rata masyarakat penambang tinggal hanya pada jarak 10 $15 \mathrm{~m}$ dari sungai. Hasil survey menunjukkan bahwa masyarakat ini hidup dan mengolah hasil emas mereka di tempat mereka tinggal. Banyak juga masyarakat yang melakukan pengolahan emas disamping atau di belakang rumah. Kegiatan pengolahan emas ini menggunakan merkuri dan limbahnya dibuang di sepanjang Sungai Pasolo. Hal ini menyebabkan masyarakat dapat terkontaminasi merkuri dengan mudah baik dari air maupun udara yang mereka hirup.

Hasil penelitian yang dilakukan oleh Mahmud dkk, (2016) menunjukkan merkuri pada ikan, telah berada di atas baku mutu yang disyarakan dimana konsentrasi merkuri tertinggi pada ikan batu Snapper 2.2977 $\mathrm{mg} / \mathrm{kg}$ dan terendah sebesar $0.3154 \mathrm{mg} / \mathrm{kg}$ pada Ikan Kerapu (Goropa tikus) (Epinephelus Bleekeri) dengan berat 140 gram. Hasil rata-rata menunjukkan bahwa ikan di perairan Sumalata telah terkontaminasi merkuri sebesar $1.254 \mathrm{mg} / \mathrm{kg}$. Berdasarkan hasil ini maka besar kemungkinan jalur masuk merkuri pada manusia di Penambangan Emas Buladu melalui ikan yang mereka makan setiap hari. Hal ini diperkuat oleh penelitian yang dilakukan oleh Raymond et al. (2017) yang menunjukkan bahwa konsentrasi merkuri berkorelasi secara positif dengan konsumsi ikan dan karakteristik demografi. Penyedia layanan kesehatan harus mendorong kebiasaan konsumsi ikan berisiko rendah pada wanita dan mengidentifikasi wanita yang membutuhkan pendidikan dan konseling.

Merkuri dapat masuk ke tubuh manusia melalui tiga cara yaitu melalui pencernaan yaitu dengan mengkonsumsi ikan, kerang, cumi dan ikan laut lainnya yang mengandung $\mathrm{MeHg}$, cara kedua adalah melalui pernapasan, yaitu dengan menghirup $\mathrm{Hg}$ yang diperoleh dari berbagai sumber, seperti uap merkuri dari hasil pembakaran amalgam, amalgam, amalgam gigi dan udara. Cara ketiga melalui penyerapan kulit Mengurangi konsumsi ikan yang terpapar $\mathrm{MeHg}$ sangatlah penting dilakukan karena akan berdampak terhadap kesehatan (Susanti, 2013). Penelitian yang dilakukan oleh Sari et al. (2012) di Iran mennjukkan bahwa wanita hamil dianjurkan untuk mengurangi makan daging ikan, khususnya ikan predator dan mengurangi konsumsi ikan dengan tertentu yang memiliki merkuri tingkat rendah. Diharapkan pemerintah untuk menghasilkan program yang mengatur konsumsi ikan. Bukan hanya karena resiko kontaminasi merkuri tetapi juga manfaat nutrisi dapat dipertimbangkan ketika mengatur standar untuk ikan dan kerang.

Pengaruh toksisitas merkuri pada manusia tergantung pada bentuk komposisi merkuri, rute masuknya ke dalam tubuh dan lamanya ekspose. Bentuk organik seperti metal-merkuri, sekitar 99\% diabsorbsi oleh di dinding usus, hal ini jauh lebih besar daripada bentuk inorganik $\left(\mathrm{HgCl}_{2}\right)$ yang hanya sekitar $10 \%$. Akan tetapi bentuk merkuri organik ini kurang bersifat korosif darpada inorganik. Bentuk organik tersebut juga dapat menembus barier darah dan placenta sehingga dapat menimbulkan pengaruh teratogenik dan gangguan saraf. Diagnosis toksisitas $\mathrm{Hg}$ tidak dapat dilakukan dengan tes biokimia. Indikator toksisitas $\mathrm{Hg}$ hanya dapat didiagnosis dengan analisis kadar $\mathrm{Hg}$ dalam darah atau urin dan rambut. Uap $\mathrm{Hg}$ yang murni merupakan permasalahan toksikologi yang unik, karena elemen $\mathrm{Hg}$ ini mempunyai dua sifat toksisitas yang sangat berbahaya pada manusia (Darmono, 2008).

Masalah pertama elemen hg dapat menembus membran sel karena ia mempunyai sifat mudah sekali larut dan lipida, sehingga mudah sekali menembus barier darah otak yang akhirnya terakumulasi di dalam otak. Masalah kedua elemen $\mathrm{Hg}$ sangat mudah seakli teroksidasi untuk membentuk merkuri oksida $(\mathrm{HgO})$ atau ion merkuri $\left(\mathrm{Hg}^{2+}\right)$. Toksisitas kronik dari kedua bentuk merkuri akan berpengaruh pada jenis organ yang berbeda yaitu saraf pusat dan ginjal (Darmono, 2008).

Kern dan Geier (2016) mengungkapkan bahwa merkuri memberi pengaruh terhadap Autism Spectrum Disorders (ASD). Hasil telaah dari 91 studi yang menguji antara merkuri dengan ASD dari 1999 sampai 2016 menunjukkan, sebagian besar dari studi ini (74\%) menyarankan bahwa merkuri adalah sebuah faktor yang berisiko terhadap ASD baik pengaruh langsung maupun tidak langsung. Sebagian besar paparan merkuri memberikan kontribusi terhadap ASD.

Toksisitas uap merkuri melalui saluran pernapasan (inhalasi) biasanya menyerang system saraf pusat, sedangkan toksisitas kronik yang ditimbulkan dapat menyerang ginjal. Elemen merkuri dan komponen alkil merkuri yang masuk ke dalam otak akan menyebabkan terjadinya perubahan struktur protein dan system enzim, sehingga sinoptik dan transmisi neuromuskuler diblok.

Toksisitas organik menimbulkan toksisitas yang sangat berbahaya. Kasus toksisitas metal merkuri pada orang baik anak maupun dewasa. Sistem syaraf pusat adalah target organ dan toksisitas metal merkuri tersebut, sehingga gejala yang terlihat erat hubungannya dengan kerusakan saraf pusat. Menurut Darmono (2008) gejala yang timbul dari toksisitas metal merkuri adalah :

a. Gangguan saraf sensoris : paraesthesia, kepekaan menurun dan sulit menggerakkan jari tangan dan kaki, penglihatan menyembupit, daya pendengaran menurun, serta rasa nyeri pada lengan dan paha.

b. Gangguan saraf motorik : lemah, sulit berdiri, mudah jatuh, ataksia, tremor, gerakan lambat dan sulit berbicara. 
c. Gangguan lain : gangguan mental, sakit kepala dan hipersalivasi.

Berdasarkan hal ini perlu segera melakukan pengelolaan lokasi penambangan tradisional Buladu. Jika tidak dikelola, maka sudah akan mengancam jiwa .masyarakat yang hidup di sepanjang Pantai Sumalata. Dimana ikan yang hidup telah tercemar dengan merkuri dan sudah berada di atas baku mutu yang ditetapkan yakni $0.5 \mathrm{mg} / \mathrm{kg}$. Konsentrasi pada manusia rata-rata sudah berkisar sebesar $55.09 \mathrm{mg} / \mathrm{kg}$. Penelitian ini sangat penting karena Gorontalo Utara sudah merupakan wilayah darurat merkuri yang harus segera dilakukan penanganannya.

\section{Kesimpulan}

Hasil penelitian konsentrasi merkuri tertinggi sebesar $952.85 \mathrm{mg} / \mathrm{kg}$ dan terendah sebesar $0.03 \mathrm{mg} / \mathrm{kg}$ dengan rata-rata konsentrasi merkuri sebesar 55.09 $\mathrm{mg} / \mathrm{kg}$. Hasil ini telah berada di atas ambang baku mutu yang ditetapkan olen NCR sebanyak 12 ppm Hasil penelitian menunjukkan bahwa konsentrasi merkuri di rambut kepala bagi masyarakat di Penambangan Emas Buladu, dari 20 sampel, 20\% melebihi batas ambang yang ditetapkan, 20\% cenderung mendekati batas ambang dan $60 \%$ berada di bawah ambang batas yang direkomendasikan oleh NCR sebesar 12 ppm. Berdasarkan hasil ini maka masyarakat yang bermukim di lokasi penambangan emas Buladu telah terkontaminasi merkuri.

\section{Ucapan Terima Kasih}

Ucapan terima kasih kepada Kemenristekdikti yang telah memberikan bantuan dana dan ucapan terima kasih kepada Rektor, Kepala Lembaga Penelitian dan semua pihak yang telah membantu dalam penyelesaian penelitian ini. Penulis mengucapkan terima kasih kepada semua penulis buku yang dijadikan sumber pada telaah pustaka ini.

\section{Daftar Pustaka}

[1] Asiah, N., Z. Alfian, J. Anwar, Y. Siregar, D. Bangun, 2015. Pengaruh Lama Kerja Terhadap Kadar Merkuri (Hg) Dalam Urin Pekerja Tambang Emas (Studi Kasus di Desa Panton
Luas Kecamatan Sawang Kabupaten Aceh Selatan). Jurnal Pendidikan Kimia (JPKim) ISSN: 2085-3653. 7(2), pp. 7-12.

[2] Brabo, E.S., R.S. Angelica, A.P. Silva, K.R.F. Faial, A.F.S Mascarenhas, E.C.O. Santos, M. Jesus, dan E.C.B. Loureiro, 2003. Assessment of Mercury Levels in Soils, Waters, Bottom Sediments and Fishes of Acre State in Brazilian Amazon. Water, Journal Air and Soil Pollution. 147, pp. 61-77.

[3] Chamid, C., N. Yulianita, P. Renosori, 2010. Kajian Tingkat Konsentrasi Merkuri (Hg) Pada Rambut Masyarakat Kota Bandung.Prosiding SNaPP Edisi Eksakta. pp. 107-131.

[4] Darmono, 2008. Lingkungan Hidup dan Pencemaran Hubungannya dengan Toksikologi Senyawa Logam. UI Press. Jakarta.

[5] Junita N.R., 2013. Risiko Keracunan Merkuri (Hg) pada Pekerja Penambangan Emas Tanpa Izin (PETI) di Desa Cisarua Kecamatan Nanggung Kabupaten Bogor. Skripsi. Program Studi Kesehatan Masyarakat Fakultas Kedokteran dan Ilmu Kesehatan Universitas Islam negeri Syarif Hidayatullah Jakarta.

[6] Kern, J.K., M.R. Geier, 2016. The Relationship Between Mercury and Autism: A Comprehensive Review and Discussion. Journal of Trace Element in Medicine and Biology. 37, pp. 8-24.

[7] Mahmud, M., 2012. Model Sebaran Spasial Temporal Konsentrasi Merkuri Akibat Penambangan Emas Tradisional Sebagai Dasar Monitoring dan Evaluasi Pencemaran di Ekosistem Sungai Tulabolo Provinsi Gorontalo. Disertasi. Program Studi Geografi. Universitas Gadjah Mada, Yogyakarta.

[8] Mahmud, M., Lihawa. F., I. Patuti, 2014. Kajian pencemaran Merkuri terhadap Lingkungan di Kabupaten Gorontalo Utara. Laporan Penelitian PNBP, Universitas Negeri Gorontalo.

[9] Mahmud, M., F. Desei, B.C. Banteng, Y. Saleh, 2016. Model Pengelolaan Penambangan Emas Tradisional Buladu Kabupaten Gorontalo Utara. Laporan Penelitian PUPT. Tahun I, Universitas Negeri Gorontalo. Gorontalo.

[10] Panda, A., K.H. Nitimulyo, dan T.S. Djohan, 2003. Akumulasi Merkuri pada Ikan Baung (Mytus nemurus) di Sungai Kahayan Kalimantan Tengah. Jurnal Manusia dan Lingkungan. 10(3), November 2003.

[11] Raymond, M.S., Michelle, Christensen, Y. Krista, Thompson, M.P.H. Brooke, Anderson, M.D. Hendry, 2017. Changes in Hair Mercury Levels Among Women of Child-Bearing Age Following an Educational Intervention. Journal of Occupational dan Environmental Medicine. 59(6), pp. 528534.

[12] Sari, A.E., E. Abdollahzadeh, S.J. Shooshtari, S.M. Ghasempouri, 2012. Hair Mercury in Six Iranian Subpopulations for Estimation of Methylmercury Exposure : A Mini-review. Iranian Journal of Toxicology. 5(15), pp. 541547.

[13] Susanti, H.D., 2013. Transport Metilmerkuri (MeHg) dan Merkuri Inorganik (I-Hg) Terhadap Janin dan Asi. Jurnal Keperawatan. 4(2), pp. 109-115.

[14] Xing, X, Du, Rong., Li, Yufeng., Li, Bai., Cai, Quan., Mo, Guang., Gong, Yu, 2013. Structural Change of Human Hair Induced by Mercury Exposure. Environmental Science and Technology. 47, ACS Publications.

[15] Rumatoras, H., Taipabu M.I., Lesiela, L., Male, Y.T, 2016. Analisis Kadar Merkuri (Hg) Pada Rambut Penduduk Desa Kayeli, Akibat Penambangan Emas Tanpa Ijin di Areal Gunung Botak Kabupaten Buru Provinsi Maluku. Indonesian Journal of Chemistry Research 3. pp. 290-294. 